\title{
Artificial intelligence in seeding density optimization and yield simulation for oat
}

\author{
Eldair F. Dornelles ${ }^{1}$, Adriana R. Kraisig ${ }^{1}$, José A. G. da Silva², \\ Sandro Sawicki ${ }^{1}$, Fabricia Roos-Frantz ${ }^{1} \&$ Roberto Carbonera ${ }^{2}$ \\ ${ }^{1}$ Universidade Regional do Noroeste do Estado do Rio Grande do Sul/Departamento de Ciências Exatas e Engenharias. Ijuí, RS. E-mail: eldair.dornelles@gmail.com \\ (Corresponding author) - ORCID: 0000-0001-6585-3432; maryshelei@yahoo.com.br - ORCID: 0000-0002-5495-7700; sawicki@unijui.edu.br - ORCID: \\ 0000-0002-7960-0775; frfrantz@unijui.edu.br - ORCID: 0000-0001-9514-6560 \\ ${ }^{2}$ Universidade Regional do Noroeste do Estado do Rio Grande do Sul/Departamento de Estudos Agrários. Ijuí, RS. E-mail: jagsfaem@yahoo.com.br - ORCID: \\ 0000-0002-9335-2421; carbonera@unijui.edu.br - ORCID: 0000-0001-8686-2047
}

\section{Key words:}

Avena sativa artificial neural networks genetic algorithms innovation

\begin{abstract}
A B S T R A C T
Artificial intelligence may represent an efficient strategy for simulation and optimization of important processes in agriculture. The main goal of the study is to propose the use of artificial intelligence, namely artificial neural networks and genetic algorithms, respectively, in the simulation of oat grain yield and optimization of seeding density, considering the main succession systems of southern Brazil. The study was conducted in a randomized complete block design with four replicates, following a $4 \times 2$ factorial scheme, for seeding densities $\left(100,300,600\right.$ and 900 seeds $\left.\mathrm{m}^{-2}\right)$ and oat cultivars (Brisasul and URS Taura), in succession systems of corn/oats and soybean/oats. A multi-layered artificial neural network and a genetic algorithm were implemented in Java programming language, and the results obtained from this implementation were compared with traditional polynomial regression. The use of artificial intelligence through neural networks and genetic algorithms allows the efficient simulation of oat grain yield and better optimization of seeding density in comparison to polynomial regression, considering the main succession systems in southern Brazil.
\end{abstract}

\author{
Palavras-chave: \\ Avena sativa \\ redes neurais artificiais \\ algoritmos genéticos \\ inovação
}

\section{Inteligência artificial na otimização da densidade de semeadura e simulação da produtividade da aveia}

\section{R E S U M O}

O uso de inteligência artificial pode representar uma estratégia eficiente de simulação e otimização de processos importantes na agricultura. O objetivo deste estudo é propor o uso de inteligência artificial via redes neurais artificiais e algoritmos genéticos, respectivamente, na simulação da produtividade de grãos de aveia (Avena sativa) e na otimização da densidade de semeadura, nos principais sistemas de sucessão do sul do Brasil. O estudo foi conduzido em blocos ao acaso com quatro repetições em esquema fatorial 4 x 2, para as densidades de semeadura $\left(100,300,600\right.$ e 900 sementes $\mathrm{m}^{-2}$ ) e cultivares de aveia (Brisasul e URS Taura), nos sistemas de sucessão milho/aveia e soja/aveia. Implementou-se uma rede neural artificial de múltiplas camadas e um algoritmo genético, em linguagem de programação Java, e comparou-se os resultados obtidos desta implementação com análises tradicionais de regressão polinomial. $O$ uso de inteligência artificial via redes neurais artificiais e algoritmos genéticos permite simular com eficiência a produtividade de grãos de aveia e melhor otimização da densidade de semeadura na comparação com regressão polinomial, considerando os principais sistemas de sucessão no sul do Brasil. 


\section{INTRODUCTION}

Computer techniques have great relevance in the simulation and optimization in various areas (Krug et al., 2015; Barbosa et al., 2016). Simulation models are essential in the identification of factors that influence agricultural production and moreefficient managements (Mello \& Caimi, 2008; Leal et al., 2015). Artificial intelligence (AI) techniques have emerged as an alternative in the development of simulation and optimization models (Leal et al., 2015; Soares et al., 2015). Among AI techniques, artificial neural networks (ANNs) present a mathematical model inspired in the neural structure of intelligent organisms, capable of performing computer learning and pattern recognition (McCulloch \& Pitts, 1943; Çelebi et al., 2017). Genetic algorithm is also an AI technique inspired in the mechanisms of evolution of living organisms, which promote agility in the formulation and solution of optimization problems (Bento \& Kagan, 2008; Zheng et al., 2017).

Oat (Avena sativa) is one of the most cultivated species in southern Brazil, for soil cover, crop rotation and food production (Castro et al., 2012; Hawerroth et al., 2015). Studies aiming at simulation and optimization with the oat crop through AI via artificial neural networks and genetic algorithms are inexistent in the Brazilian research, although they can contribute to important processes related to the management of the species. Since the expression of oat grain yield depends on seeding density (Silva et al., 2012; Romitti et al., 2017), using different densities in the alteration of grain yield may serve as basis for training the network and validate the use of AI for simulation and optimization.

This study aimed to propose the use of artificial intelligence via artificial neural networks and genetic algorithms in the simulation of oat grain yield and optimization of seeding density, respectively, in the main succession systems of southern Brazil.

\section{Material AND Methods}

The experiment was carried out in the field, in 2016, in the municipality of Augusto Pestana, RS, Brazil (28²6’ $30^{\prime \prime}$ S; $54^{\circ}$ $\left.00^{\prime} 58^{\prime \prime} \mathrm{W}\right)$. The soil of the experimental area is classified as typic dystroferric Red Latosol and the climate of the region, according to Köppen's classification, is Cfa, with hot summer without dry season. Sowing was performed in the first week of June using a seeder-fertilizer machine. The plot consisted of five 5 - $\mathrm{m}$-long rows spaced by $0.20 \mathrm{~m}$, totaling an experimental unit of $5 \mathrm{~m}^{2}$. Applications of the fungicide Tebuconazole were made at dose of $0.75 \mathrm{~L} \mathrm{ha}^{-1}$. Weeds were controlled using the herbicide metsulfuron-methyl at dose of $4 \mathrm{~g} \mathrm{ha}^{-1}$.

The experiments were conducted in two cultivation systems, involving the cover of soil by plant residues with high and reduced $\mathrm{C} / \mathrm{N}$ ratios, corn/oat and soybean/oat systems, respectively. In each system, the experimental design was randomized complete blocks with four replicates, in a 4 x 2 factorial scheme, for seeding densities (100, 300, 600 and 900 viable seeds $\mathrm{m}^{-2}$ ) and oat cultivars (Brisasul and URS-Taura), respectively. The cultivars used represent the standard biotype desired in the commercial plantations of southern Brazil, with short cycle, reduced size and resistant to lodging, but differing for the tillering capacity (Brisasul: high; URS Taura: reduced). Yield was obtained by cutting the three central rows of each plot at harvest maturity point and threshing in stationary threshing machine. Then, plants were taken to the laboratory to correct grain moisture to $13 \%$ and weighed to estimate grain yield (GY, $\mathrm{kg} \mathrm{ha}^{-1}$ ).

A multi-layered ANN was implemented in Java programming language to simulate oat yield by the different seeding densities. ANN structure was composed of three layers, containing 1 neuron in the input layer, 3 neurons in the hidden layer and 1 neuron in the output layer. The ANN was trained using the backpropagation algorithm (Riedmiller \& Braun, 1993), considering seeding density as input data and grain yield as output data. ANN training was performed individually for each cultivar and succession system, with $70 \%$ of the data used for training and 30\% for validation.

A genetic algorithm was implemented in the Java programming language for the optimization of ideal seeding density, with definition of a population of 100 individuals and a limit of 50 generations, fixing mutation rate at $5 \%$ and elitism rate at $2 \%$. In the selection process, the roulette wheel method was used; in the crossover, the method called single-point or simple method was used (Golmohammadi et al., 2016), the ones with best fits based on the optimization tests.

Data obtained in the field regarding the different seeding densities were subjected to second-order polynomial regression analysis, commonly used in the optimization and simulation of factors with quantitative training levels (Romitti et al., 2017). After meeting the assumptions of homogeneity and normality by Bartlett's test, analysis of variance of regression was conducted to detect main and interaction effects. Based on this information, a second-order equation ( $G Y=b_{0} \pm b_{1} \mathrm{x}$ $\left.\pm \mathrm{b}_{2 \mathrm{x}}{ }^{2}\right)$ was fitted for optimizing seeding density to maximum technical efficiency $\left(\mathrm{MTE}=-\mathrm{b}_{1} / 2 \mathrm{~b}_{2}\right)$ and then grain yield was simulated based on the optimal density obtained. Results of optimization and simulation through regression were used as reference for comparison with the results of optimization and simulation through artificial intelligence via genetic algorithms and artificial neural networks, respectively.

\section{Results AND Discussion}

In the soybean/oat system, the grain yields of the oat cultivars were similar to those obtained by simulation via ANN, regardless of the seeding densities evaluated (Table 1 ). In this system, there was a trend of increase in grain yield at the points of 300 and 600 seeds $\mathrm{m}^{-2}$, with yield reduction at the highest density. This same behavior occurred with the simulation via ANN, which gives consistency to the use of the artificial intelligence techniques employed.

In the corn/oat system, the actual values of grain yield and those obtained by simulation also evidenced high similarity (Table 1). In this system, the increase in seeding density also favored greater expression of grain yield, but with different behaviors between both cultivars. The values of the cultivar URS Taura showed greater expression of grain yield at the 
Table 1. Values observed and simulated by artificial neural network for oat grain yield at different seeding densities in the succession systems

\begin{tabular}{|c|c|c|c|c|c|c|c|c|}
\hline \multirow{2}{*}{ Genotype } & \multicolumn{2}{|c|}{100 seeds $\mathrm{m}^{-2}$} & \multicolumn{2}{|c|}{300 seeds $\mathrm{m}^{-2}$} & \multicolumn{2}{|c|}{600 seeds $\mathrm{m}^{-2}$} & \multicolumn{2}{|c|}{900 seeds $\mathrm{m}^{-2}$} \\
\hline & $\mathrm{GY}_{0}$ & $\mathrm{GY}_{\mathrm{S}}$ & $\mathrm{GY}_{0}$ & $\mathrm{GY}_{\mathrm{S}}$ & $\mathrm{GY}_{0}$ & $\mathrm{GY}_{\mathrm{s}}$ & $\overline{\mathrm{GY}}$ & $\mathrm{GY}_{\mathrm{S}}$ \\
\hline \multicolumn{9}{|c|}{ Soybean/oat system - Grain yield (kg ha-1) } \\
\hline URS Taura & 2753 & 2757 & 3268 & 3268 & 3443 & 3443 & 2737 & 2739 \\
\hline Brisasul & 2687 & 2688 & 3857 & 3857 & 3668 & 3668 & 2223 & 2224 \\
\hline Overall mean & 2720 & 2722.5 & 3562.5 & 3562.5 & 3555.5 & 3555.5 & 2480 & 2481.5 \\
\hline \multicolumn{9}{|c|}{ Corn/oat system - Grain yield $\left(\mathrm{kg} \mathrm{ha}^{-1}\right)$} \\
\hline URS Taura & 2171 & 2171 & 2764 & 2764 & 3034 & 3033 & 2912 & 2913 \\
\hline Brisasul & 2080 & 2082 & 2865 & 2865 & 2959 & 2959 & 2464 & 2465 \\
\hline Overall mean & 2125.5 & 2126.5 & 2814.5 & 2814.5 & 2546.5 & 2996 & 2688 & 2689 \\
\hline
\end{tabular}

$\mathrm{GY}_{0}$ - Grain yield observed under actual field conditions; $\mathrm{GY}_{\mathrm{s}}$ - Grain yield simulated by artificial intelligence via artificial neural networks

points of 600 and 900 seeds $\mathrm{m}^{-2}$. On the other hand, the cultivar Brisasul exhibited higher actual yields at the points of 300 and 600 seeds $\mathrm{m}^{-2}$. These responses were expected because it is a more restrictive system of residual $\mathrm{N}$ and due to the lower tillering capacity of the cultivar URS Taura, which demands higher number of seeds per area. The obtained actual conditions that differentiated the behavior of the cultivars in the succession system were also recognized by simulation system via artificial intelligence, reinforcing the possibility of using this tool in the simulation of oat cultivation processes.

The use of artificial neural networks has presented itself as an efficient alternative to conventional models in the recognition of patterns and simulation of cultivation processes (Silva et al., 2014; Soares et al., 2014). Rogenski et al. (2012) found efficiency of the artificial neural networks in the estimation of infection percentage of leaf diseases in wheat, as assistance in decision-making. Soares et al. (2015) observed the possibility of using artificial neural networks in the estimation of corn grain yield, considering the morphological variables of the crop. The efficiency of artificial neural networks in the processes of simulation was also observed by Soares et al. (2014) in the estimation of bean yield. Castro et al. (2013) proposed the use of artificial neural networks in the modeling of growth and stand of eucalyptus located in northern Brazil.

Promising results with the use of artificial neural networks were found by Leal et al. (2015) adopting soil attributes in the simulation of corn grain yield. In study on adaptability and stability of cowpea, Teodoro et al. (2015) found similarity of the parameters obtained by the traditional method of Eberhart \& Russel (1966) and the use of artificial neural networks.

One of the simplest strategies to program the irrigation calendar is the use of reference evapotranspiration. Resende
\& Oliveira (2005) conducted studies to increase the accuracy in evapotranspiration calculation by artificial neural networks, obtaining great success. Moreira \& Cecílio (2008), through artificial neural networks, obtained monthly and annual estimates of minimum, mean and maximum air temperatures in the Northeast region of Brazil, allowing for higher accuracy in comparison to the regression equations found in the specialized literature.

In the optimization and simulation of oat seeding density in the soybean/oat system (Table 2), the cultivar URS Taura showed through the regression equation an ideal seeding density of 510 seeds $\mathrm{m}^{-2}$, and expected grain yield of $3480 \mathrm{~kg} \mathrm{ha}^{-1}$. The ideal seeding density with the use of genetic algorithms was 480 seeds $\mathrm{m}^{-2}$ and yield simulation by artificial neural networks of $3560 \mathrm{~kg} \mathrm{ha}^{-1}$. In the cultivar Brisasul, the seeding density through regression was 460 seeds $\mathrm{m}^{-2}$ and expected yield was $3960 \mathrm{~kg} \mathrm{ha}^{-1}$. In this cultivar, the use of genetic algorithm indicated optimal density of 400 seeds $\mathrm{m}^{-2}$ with simulation of an expected yield of $3990 \mathrm{~kg} \mathrm{ha}^{-1}$.

The results for the soybean/oat system demonstrate high similarity of yields obtained by regression and artificial neural networks. In addition, optimization via genetic algorithms showed the possibility of lower number of seeds in the tested cultivars, maintaining the same expected yield. Emphasis is also given to the efficiency of the artificial intelligence techniques in the recognition of patterns between the cultivars, indicating higher seeding density for URS Taura, due to the genetic characteristic of lower expression of tillering.

In the corn/oat system, the cultivar URS Taura showed seeding density fitted by regression of 650 seeds $\mathrm{m}^{-2}$ and expected yield of $3080 \mathrm{~kg} \mathrm{ha}^{-1}$. The ideal seeding density

Table 2. Analysis of regression and artificial intelligence in the optimization of seeding density and simulation of oat grain yield

\begin{tabular}{|c|c|c|c|c|c|c|c|}
\hline \multirow[b]{2}{*}{ Genotype } & \multicolumn{5}{|c|}{ Regression } & \multicolumn{2}{|c|}{ Artificial Intelligence } \\
\hline & $y=a \pm b x \pm c x^{2}$ & $\mathrm{R}^{2}$ & $\begin{array}{c}P \\
\left(c x^{2}\right)\end{array}$ & $\begin{array}{c}\text { ID } \\
\left(s \mathrm{~m}^{-2}\right)\end{array}$ & $\begin{array}{c}\mathrm{GY}_{\mathrm{S}} \\
\left(\mathrm{kg} \mathrm{ha}^{-1}\right)\end{array}$ & $\begin{array}{l}\text { ID (GA) } \\
\left(\mathrm{s} \mathrm{m}^{-2}\right)\end{array}$ & $\begin{array}{c}\mathrm{GY}_{\mathrm{S}} \text { (ANN) } \\
\left(\mathrm{kg} \mathrm{ha}^{-1}\right)\end{array}$ \\
\hline \multicolumn{8}{|c|}{ Soybean/oat system } \\
\hline URS Taura & $2333+4.55 x-0.0045 x^{2}$ & 0.99 & * & 510 & 3480 & 480 & 3560 \\
\hline Brisasul & $1992+8.51 x-0.0092 x^{2}$ & 0.98 & * & 460 & 3960 & 400 & 3990 \\
\hline Overall Mean & - & - & & 485 & 3720 & 440 & 3775 \\
\hline \multicolumn{8}{|c|}{ Corn/oat system } \\
\hline URS Taura & $1842+3.79 x-0.0029 x^{2}$ & 0.99 & * & 650 & 3080 & 540 & 3040 \\
\hline Brisasul & $1655+5.14 x-0.0047 x^{2}$ & 0.96 & * & 550 & 3060 & 460 & 3020 \\
\hline Overall Mean & - & - & & 600 & 3070 & 500 & 3030 \\
\hline
\end{tabular}

$\mathrm{R}^{2}$ - Coefficient of determination; $\mathrm{P}\left(\mathrm{cx} \mathrm{x}^{2}\right)$ - Probability of the regression equation slope parameter at 0.05 probability level; ${ }^{*}$ - Significant at 0.05 probability level; ID - Ideal density obtained by regression; $\mathrm{GY}_{\mathrm{F}}$ - Grain yield estimated by regression using ideal density; ID $(\mathrm{GA})$ - Ideal density obtained by artificial intelligence via genetic algorithms; GY $(\mathrm{ANN})-\mathrm{Grain}_{\mathrm{i}}$ yield estimated by artificial intelligence via artificial neural networks 
using genetic algorithms was 540 seeds $\mathrm{m}^{-2}$ and the expected yield through artificial neural networks was $3040 \mathrm{~kg} \mathrm{ha}^{-1}$. In the cultivar Brisasul, the ideal seeding density was 550 seeds $\mathrm{m}^{-2}$, with expected yield of $3060 \mathrm{~kg} \mathrm{ha}^{-1}$. In this cultivar, the ideal density through genetic algorithm was 460 seeds $\mathrm{m}^{-2}$ and the yield estimated by ANN was $3020 \mathrm{~kg} \mathrm{ha}^{-1}$. Regardless of the cultivar, the similarity between yields estimated by regression and ANN was also found and with higher quality of optimization via genetic algorithms, indicating reduction in the use of seeds with similar expected yield.

The recognition of patterns by artificial intelligence between the cultivation systems was also identified, showing through the overall mean (Tables 1 and 2) higher grain yield in the soybean/oat system compared with the corn/oat system. In addition, the necessity of higher seed density for the corn/ oat system, especially using the cultivar URS Taura, with lower tillering capacity, was recognized. According to Figure 1 , the expression of oat grain yield as a function of seeding density via artificial intelligence and polynomial regression demonstrates the same trend of behavior, thus proving the efficiency of these techniques for simulation and optimization in the oat crop management, representing a tool of assistance to decision-making.

A.

URS Taura (soybean/oat)

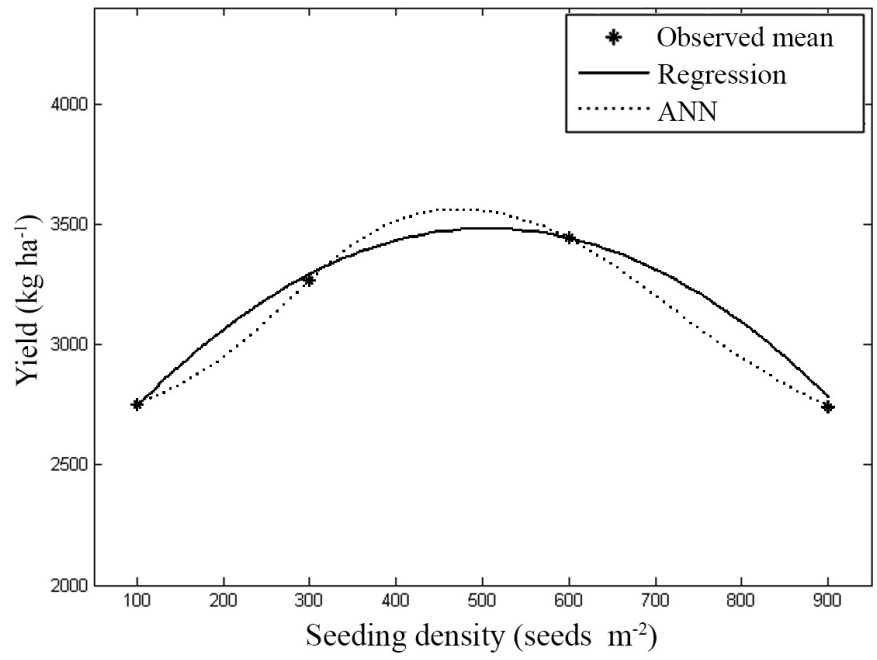

C.

URS Taura (corn/oat)

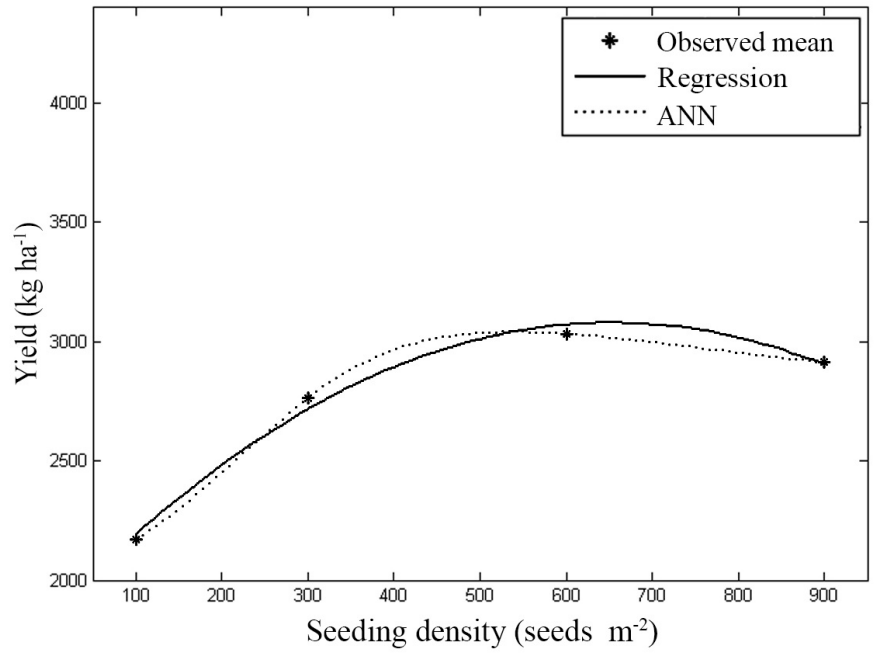

The technique of artificial intelligence by genetic algorithm has been employed in different areas seeking solutions for optimization problems (Miranda et al., 2015; Salvino et al., 2015). The use of genetic algorithm was reported by Costa et al. (2010) in the reduction of energy costs in water supply systems. Salvino et al. (2015) used genetic algorithm to identify irregularities in water distribution systems in cities. Simões \& Ebecken (2016) proved the efficiency of genetic algorithms in the optimization of supports for refinery ovens. Barbosa \& Lobato (2016) indicated the use of genetic algorithms in the optimization process, in the estimation of drying kinetic parameters of food products. By using genetic algorithms, Ferreira Neto et al. (2011) optimized the spatial organization of areas in agrarian reform projects by the yield index of the crops according to the soil suitability class. However, informatization of the rural environment is an inevitable evolution and the manipulation of large amount of data is only possible using computer methods and resources (Barbosa, 2011). Therefore, the solution of problems through artificial intelligence in the use of artificial neural networks and genetic algorithms is very attractive, creating the possibility of superior performance compared with validated conventional models.

$\mathrm{B}$

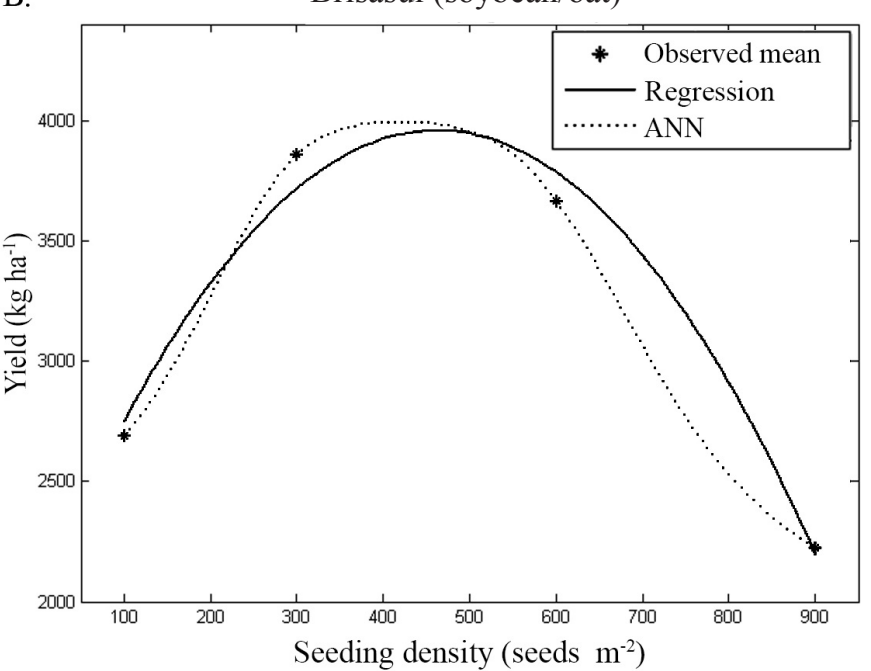

D.

Brisasul (corn/oat)

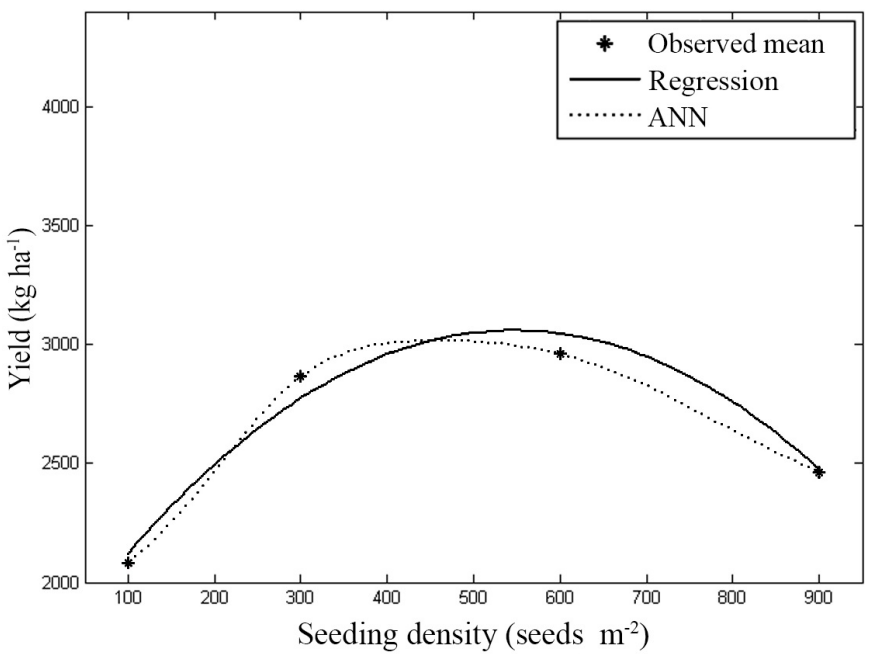

Figure 1. Observed behavior of grain yield via regression and artificial neural network (ANN): soybean/oat system (URS Taura) (A), soybean/oat system (Brisasul) (B), corn/oat system (URS Taura) (C) and corn/oat system (Brisasul) (D) 


\section{Conclusion}

The use of artificial intelligence via artificial neural networks and genetic algorithms allows to efficiently simulate oat grain yield and with better optimization of seeding density, compared with the polynomial regression, considering the main succession systems in southern Brazil.

\section{ACKnowledgments}

To the Coordination for the Improvement of Higher Education Personnel (CAPES), National Council for Scientific and Technological Development (CNPq), Rio Grande do Sul Research Support Foundation (FAPERGS) and the Regional University of the Northwest of Rio Grande do Sul (UNIJUÍ), for the financial support to the research and for the Scientific and Technological Initiation scholarship, Postgraduate scholarship and Research Productivity Grant.

\section{Literature Cited}

Barbosa, C. D. Rede neural artificial aplicada à agricultura. Vértice, v.13, p.161-170, 2011.

Barbosa, J. Z.; Consalter, R.; Pauletti, V.; Motta, A. C. V. Uso de imagens digitais obtidas com câmeras para analisar plantas. Revista de Ciências Agrárias, v.39, p.15-24, 2016. https://doi.org/10.19084/ RCA15006

Barbosa, T. A.; Lobato, F. S. Determinação da cinética de secagem de produtos alimentícios usando algoritmos genéticos. Revista de Agricultura Neotropical, v.3, p.28-37, 2016.

Bento, E. P.; Kagan, N. Algoritmos genéticos e variantes na solução de problemas de configuração de redes de distribuição. Sba: Controle \& Automação Sociedade Brasileira de Automatica, v.19, p.302315, 2008. https://doi.org/10.1590/S0103-17592008000300006

Castro, G. S. A.; Costa, C. H. M. da; Ferrari Neto, J. Ecofisiologia da aveia branca. Scientia Agraria Paranaensis, v.11, p.1-15, 2012. https://doi.org/10.18188/1983-1471/sap.v11n3p1-15

Castro, R. V. O.; Soares, C. P. B. ; Leite, H. G.; Souza, A. L. de; Nogueira, G. S.; Martins, F. B. Individual growth model for eucalyptus stands in Brazil using artificial neural network. ISRN Forestry, v.2013, p.1-12, 2013. https://doi.org/10.1155/2013/196832

Costa, L. H. M.; Castro, M. A. H. de; Ramos, H. Utilização de um algoritmo genético híbrido para operação ótima de sistemas de abastecimento de água. Engenharia Sanitaria e Ambiental, v.15, p.187-196, 2010. https://doi.org/10.1590/S141341522010000200011

Çelebi, K.; Uludamar, E.; Tosun, E.; Yildizhan, S.; Aydin, K.; Ozcanli, M. Experimental and artificial neural network approach of noise and vibration characteristic of an unmodified diesel engine fuelled with conventional diesel, and biodiesel blends with natural gas addition. Fuel, v.197, p.159-173, 2017. https://doi.org/10.1016/j. fuel.2017.01.113

Eberhart, S. A.; Russell, W. A. Stability parameters for comparing varieties. Crop Science, v.6, p.6-40, 1966. https://doi.org/10.2135/ cropsci1966.0011183X000600010011x

Ferreira Neto, J. A.; Moreira, M. C. de O.; Santos Junior, E. C. dos; Paleo, U. F.; Lani, J. L. Aptidão agrícola e algoritmos genéticos na organização espacial em projetos de reforma agrária. Revista Brasileira de Ciência do Solo, v.35, p.255-261, 2011. https://doi. org/10.1590/S0100-06832011000100024
Golmohammadi, A. M.; Bani-Asadi, H.; Zanjani, H. J.; Tikani, H. A genetic algorithm for preemptive scheduling of a single machine. International Journal of Industrial Engineering Computations, v.7, p.607-614, 2016. https://doi.org/10.5267/j.ijiec.2016.3.004

Hawerroth, M. C.; Silva, J. A. G. da; Souza, C. A.; Oliveira, A. C. de; Luche, H. de S.; Zimmer, C. M.; Hawerroth, F. J. Schiavo, J.; Sponchiado, J. C. Redução do acamamento em aveia-branca com uso do regulador de crescimento etil-trinexapac. Pesquisa Agropecuária Brasileira, v.50, p.115-125, 2015. https://doi. org/10.1590/S0100-204X2015000200003

Krug, A. B.; Parraga, A.; Lorenzi, F.; Nicolao, M.; Morales, A. S. Análise e reconhecimento de padrões usando processamento de imagens e inteligência artificial. Revista de Iniciação Científica da ULBRA, v.7, p.145-154, 2015.

Leal, A. J. F.; Miguel, E. P.; Baio, F. H. R.; Neves, D. de C.; Leal, U. A. S. Redes neurais artificiais na predição da produtividade de milho e definição de sítios de manejo diferenciado por meio de atributos do solo. Bragantia, v.74, p.436-444, 2015. https://doi. org/10.1590/1678-4499.0140

McCulloch, W. S.; Pitts, W. H. A logical calculus of the ideas immanent in nervous activity. Bulletin of Mathematical Biophysics, v.5, p.115-133, 1943. https://doi.org/10.1007/BF02478259

Mello, B. A. de; Caimi, L. L. Simulação na validação de sistemas computacionais para a agricultura de precisão. Revista Brasileira de Engenharia Agrícola e Ambiental, v.12, p.666-676, 2008. https://doi.org/10.1590/S1415-43662008000600015

Miranda, R. de C.; Montevechi, J. A. B.; Pinho, A. F. de. Development of an adaptive genetic algorithm for simulation optimization. Acta Scientiarum. Technology, v.37, p.321-328, 2015. https://doi. org/10.4025/actascitechnol.v37i3.25986

Moreira, M. C.; Cecílio, R. A. Estimativa das temperaturas do ar utilizando redes neurais artificiais, para a região Nordeste do Brasil. Revista Brasileira de Agrometeorologia, v.16, p.181-188, 2008.

Resende, M.; Oliveira, A. C. Comparação de diferentes estratégias de programação de irrigação suplementar em milho. Revista Brasileira de Milho e Sorgo, v.4, p.205-214, 2005. https:/doi. org/10.18512/1980-6477/rbms.v4n2p205-214

Riedmiller, M.; Braun, H. A direct adaptive method for faster back propagation learning: The RPROP algorithm. In: International Conference on Neural Networks, 1, 1993, San Francisco. Anais... San Francisco: IEEE, 1993. p.586-591. https://doi.org/10.1109/ ICNN.1993.298623

Rogenski, R. A.; Zanlorensi Júnior, L. A.; Mathias, I. M. Aplicação de redes neurais artificiais para a estimativa de infecção por manchas foliares na cultura do trigo. Revista de Engenharia e Tecnologia, v.4, p.58-64, 2012.

Romitti, M. V.; Dornelles, E. F.; Silva, J. A. G. da; Marolli, A.; Mantai, R. D.; Scremin, O. B.; Arenhardt, E. G.; Brezolin, A. P.; Reginatto, D. C.; Scremin, A. H.; Lima, A. R. C. de; Silva, D. R. da. The sowing density on oat productivity indicators. African Journal of Agricultural Research, v.12, p.905-915, 2017. https://doi. org/10.5897/AJAR2016.12095

Salvino, M. M.; Carvalho, P. S. O. de; Gomes, H. P. Calibração multivariada de redes de abastecimento de água via algoritmo genético multiobjetivo. Engenharia Sanitária Ambiental, v.20, p.503512, 2015. https://doi.org/10.1590/S1413-41522015020000099484 
Silva, A. A. V. da; Silva, I. A. F.; Texeira Filho, M. C. M.; Buzetti, S.; Teixeira, M. C. M. Estimativa da produtividade de trigo em função da adubação nitrogenada utilizando modelagem neuro fuzzy. Revista Brasileira de Engenharia Agrícola e Ambiental, v.18, p.1-6, 2014. https://doi.org/10.1590/S1415-43662014000200008

Silva, J. A. G. da; Fontaniva, C.; Costa, J. S. P.; Krüger, C. A. M. B.; Ubessi, C.; Pinto, F. B.; Renhardt, E. G.; Gewber, E. Uma proposta na densidade de semeadura de um biotipo atual de cultivares de aveia. Revista Brasileira Agrociência, v.18, p.253-263, 2012.

Simões, G. J.; Ebecken, N. F. F. Algoritmo genético e enxame de partículas para a otimização de suportes laterais de fornos. Revista Internacional de Métodos Numéricos para Calculo y Diseño en Ingeniería, v.32, p.7-12, 2016. https://doi.org/10.1016/j.rimni.2014.07.001

Soares, F. C.; Robaina, A. D.; Peiter, M. X.; Russi, J. L. Predição da produtividade da cultura do milho utilizando rede neural artificial. Ciência Rural, v.45, p.1987-1993, 2015. https://doi. org/10.1590/0103-8478cr20141524
Soares, F. C.; Robaina, A. D.; Peiter, M. X.; Russil, J. L.; Vivan, G. A. Redes neurais artificiais na estimativa da retenção de água do solo. Ciência Rural, v.44, p.293-300, 2014. https://doi.org/10.1590/ S0103-84782014000200016

Teodoro, P. E.; Barroso, L. M. A.; Nascimento, M.; Torres, F. E.; Sagrilo, E.; Santos, A. dos; Ribeiro, L. P.; Redes neurais artificiais para identificar genótipos de feijão-caupi semiprostrado com alta adaptabilidade e estabilidade fenotípicas. Pesquisa Agropecuária Brasileira, v.50, p.1054-1060, 2015. https://doi.org/10.1590/S0100204X2015001100008

Zheng, Z. Y.; Guo, X. N.; Zhu, K. X.; Peng, W.; Zhou, H. M. Artificial neural network - Genetic algorithm to optimize wheat germ fermentation condition: Application to the production of two anti-tumor benzoquinones. Food Chemistry, v.227, p.264-270, 2017. https://doi.org/10.1016/j.foodchem.2017.01.077 